\title{
Application of ICT in EFL Classes: An Integrated CALL and Task-based Approach
}

\author{
Akmal, Ph.D \\ University of PGRI Semarang, Indonesia \\ (Akmal.tanjung@lycos.com)
}

\begin{abstract}
This research is about the applications of ICT for the teaching and learning of English as a foreign language (ESF classes) especially the integration of Task-Based approach and Computer Assisted Language Learning (CALL) to improve English Speaking skill of psychology students in Indonesia. The research was conducted under $R \& D$ research method. There were 174 psychology students taken as the sample $(10 \%$ out of 1.740 population).Students in control group were taught by using non-computer tools for one semester (15 class sessions with the duration of 150 minutes) while those of experiment group were equipped with CALL. Speaking rubrics were used to record their English speaking skill. The rubrics were supported by Common European Framework (CEF) scoring system. The results show that experiment group had mean of pre-test $\mathbf{6 2 . 2 7}$ and post-test was 67.87 while control group had means score of pre-test 60.53 and post-test of 61.6. From the t-test, it was found that the t-score is $3.141>t$ critical 1.973 , $d f=172$, Sig.000 (2 tailed). It means that there was a significant difference of the students' skill after joining the Integrated CALL. The interview results of the experiment group indicated that 18 students achieved the proficiency level of $\mathrm{C} 2$ and 25 students at $\mathrm{C} 1$ (total $\mathrm{C} 2+\mathrm{C} 1=49.4 \%), 28$ at B2, $15 \mathrm{~B} 1$, and $1(1.1 \%)$ at the level of $\mathrm{A2}$. At the Control group, however, it was recorded that 15 students achieved the proficiency level of $\mathrm{C} 2$ and 16 students at $\mathrm{C} 1$ (total $\mathrm{C} 2+\mathrm{C} 1=32 \%), 25$ at $\mathrm{B} 2,15 \mathrm{~B} 1$, and $6(5.7 \%)$ students at the level of $\mathrm{A2}$ (indicated by CEF rubrics). It is revealed from the experiment that among task activities that have more gaining score were debate 23.66 , problem solving 15.41 , role play 12.68 , paraphrase 9.79, and video watching 5.29 . It is concluded that CALL and Task-Based approach with its core, supporting, and synthesizing activities started from pre-task phase, task completion, and post task have significantly improved oral proficiency of the psychology students.
\end{abstract}

Key words-ICT; EFL classes; Task Base; Speaking Skill

\section{BACKGROUND}

Less attention has been given to the English Language teaching at non-English Department in which the human resources, infrastructures such as language laboratory, internet connection, English Television Channels, LCD, English journal, English newspaper, or other printed English materials were very unsatisfactory. The language laboratory, in particular, has been used only for listening purpose.
Due to the limited time (100 minutes for each classroom session) and a large class (40-85 students), only reading comprehension was taught. Alwasilah (2000) mentioned that among several characteristics of English subject given at undergraduate level Indonesia are (a) it has been part of the system for a long time, (b) it is a compulsory subject, (c) it is 2 credits, (d) taught in 1st or 2 nd semester, (e) the classes are relatively large and heterogenic, (f) they are taught by junior lecturers who do not have enough experience in teaching...(k) there is no placement test or classification according to students' ability and there is no need analysis. Furthermore, Coleman (1987) mentions that most of the English teachers in Asia, including Indonesia, are less innovative; their classrooms seems to be glued to the text book.

According to the Minister of Education, the objectives of the polytechnics, diploma programs, colleges, or universities curriculum should accommodate the societal needs, industrial needs, and professional needs (Minister of Education Decree No. 232/U/2000). The university graduates, therefore, must possess three fundamental competences: skill, knowledge, and attitude (Minister of Education Decree No. 45/U/2002). It is meant that to become successful professionals, the university graduates must possess general knowledge, organizational knowledge, business knowledge, communication skill, and interpersonal skill.

\section{THEORETICAL FRAMEWORK}

\section{A.Speaking skill}

Speaking skill is the ability to use speech appropriately in varying social context. It is the competence that the students should know what to say, to whom, and how to say it. It is also defined as the ability to function in a truly communicative setting which involves the learners in comprehending, manipulating, producing, or interacting in the target language while their attention is principally focused on meaning rather than form (Hymes,1972;Savignon,1983;Nunan,1989). Ur (1999:120) mentions that speaking is considered to be the most important skill and learning speaking becomes the greatest interest for foreign language learners. Lack of vocabulary, stumbling 
block of grammar, and inadequate opportunities are among problems during the process of English speaking (Zhengdong, 2012).

\section{B. Computer Assisted Language Learning (CALL)}

CALL known as acronym of Computer Assisted Language Learning is the search for and study of application of the computer in language teaching and learning including the use of word processing, multimedia CD-ROM, internet for language learning (Levy,1997; Felix,1998). It has been used as a tool for the language teaching for more than 40 years. It is equipped with teacher's console, student's desk, audio, video, DVD \& CD player, LCD in focus, and internet connection. Throughout its history either behavioral, communicative, or integrated CALL, it has resulted significant gain in teaching reading and writing (Liou, 1997), vocabulary building (Liu and Reed, 1995), ESP course (Leppen \& Klaja, 1995). In addition to the findings above, Mohan (1992) stated that within the environment of CALL learners are able to communicate because software provides them with visual, audio and other situational clues.

Improving listening was one of the most successful uses of CALL because multimedia computing has standard audio and video, sound recording, and text to speech (Brett,1997).CALL also has significantly improved reading and writing skills (Nagata,1998), writing and culture (Lee,1997), students' motivation (McNeil, 2000), reading and writing of adult learners (Liou,1997), writing process (Thorson,2000), error feedback (Ogata, Feng, Hada \& Yano,2000), writing environments ( Sullivan \& Pratt,1996), assisted reading (Hong, 1997), vocabulary building (Grace, 2000).

According to Warschauer (1996), particular language learning theory should be the basic of CALL application because multimedia software will not make a big impact on language teaching unless the teachers allow the students to use internet, hypermedia, animation, graphics, etc as the authentic communication tool. Therefore, researcher would like to find out its effectiveness for the teaching and learning of English Speaking skills by applying task-based approach.

\section{Task-Based Approach}

Skehan (1998) says, "Language task is defined as meaningful in its own right and linked to the real world". The tasks should have some procedure, foster communicative interaction, and focus on meaningful interaction (Long and Crookes, 1993; Ellis, 2000; Nunan, 2005; Richard \& Rogers, 2001). It infers that language is best learned and taught through interaction as the learners can exchange information and ideas with others or with teachers not for the sake of practicing language as an end but as a means of conveying and sharing ideas, opinions, and working toward the task goal.

In language pedagogy, task is interpreted as a piece of classroom work which involves learners in comprehending, manipulating, producing or interacting in the target language while their attention is principally focused on meaning rather than form (Nunan,1989:10). This definition implies that there are three major components in the task; goals, input, and activities. Goals which may refer to general outcomes such as communicative, affective, or cognitive are general intentions behind any given learning tasks. Input including letters, news paper extracts, picture stories, magazines, hotel brochures, etc, refers to the data that form the point of departure for the task. Activities specify what learners will actually do with the input (Nunan,1989:59). The task itself can be real-world tasks and pedagogical tasks (Richard \& Rogers,2001:231). The priorities in task-based approach are on the exchanging meaning and the comprehension of content of the course or subject matter that the students learn. To facilitate such priorities, the authentic of text and types of the task-based activity could not be avoided. According to Snow (1991) content can be (1) academic subjects, (2) academic skills, and (3) other skills \& themes.

Since the subject of the research is the university students with specific field of study, task based approach is assumed to be effective for the teaching and learning of Speaking skill. It is based on the reason that the students have possessed prior knowledge on the content of the course before taking English II subject.

\section{RESEARCH METHOD}

The researcher used the educational research and development (R\&D) methodology by Gall and Borg (2007).Before designing the Task-based lessons, need analysis was conducted to the students and psychology alumni who work at government, private, and non-profit organizations. After analyzing the results of the need analysis, proto-type lessons were designed and tested to a small group. The revision of the proto-types is evaluated by expert then it was applied into the classroom of psychology students who learn English for 15 class sessions (15x150 minutes). The data were analyzed by using SPSS and Common European Framework (CEF).Experiment group had the English lesson within CALL setting while students in control group did not have these facilities at their disposition.

\section{FINDINGS AND DISCUSSIONS}

From need analysis done through questionnaire to 200 psychology alumni who work at government, private, and non-profit organizations (120 questionnaire were accepted and only 113 were valid for the analysis), reflected that English Communication skill is much needed at the non-profit organizations (means 4.20) compared to 3.66 at the government offices, and 3.95 at the private companies. Problem solving skill has the highest means of 5 at the nonprofit organization, 4.7 at the government offices, and 4.51 at private institutions.

The very paramount information from the alumni feedback is that $73.9 \%$ of them felt that English Speaking was the most difficult because they virtually lack of vocabularies to express their ideas, comments, or remarks upon a particular case. It was identified that when researcher 
asked intensely about what language components should be improved during the classroom activity, a sizeable percentage (77.2\%) answered speaking skill, some odd them said translation $(72.3 \%)$, a significant number identified vocabulary $(63.1 \%)$. Surprisingly only few of the students chose writing skill $(21.8 \%)$ as the most important skill to be improved.

It is revealed from the research that the experiment group had mean of pre-test 62.27 and post-test 67.87 while control group had means score of pre-test 60.53 and post-test 61.6. From the t-test, it was found that the $\mathrm{t}$-score is $3.141>\mathrm{t}$ critical 1.973, df=172, Sig.000 (2 tailed). It means that there was a significant difference of the students' skill after joining the Integrated CALL. The interview results of the experiment group indicated that 18 students achieved the proficiency level of $\mathrm{C} 2$ and 25 students at $\mathrm{C} 1$ (total $\mathrm{C} 2+\mathrm{C} 1=\mathbf{4 9 . 4 \%}$ ), 28 at B2, $15 \mathrm{~B} 1$, and $1(1.1 \%)$ at the level of $\mathrm{A} 2$. At the Control group, however, it was recorded that 15 students achieved the proficiency level of $\mathrm{C} 2$ and 16 students at $\mathrm{C} 1$ (total $\mathrm{C} 2+\mathrm{C} 1=32 \%), 25$ at B2, $15 \mathrm{~B} 1$, and $6(5.7 \%)$ students at the level of A2. It is noted from the experiment that among learning activities or task activities that have more gaining score were; debate, problem solving, and role play (means score of debate was 23.66, which was followed by problem solving 15.41 , role play 12.68 , paraphrase 9.79 , and video watching 5.29). The conclusion is that CALL and Task-Based approach with its core, supporting, and synthesizing activities started from pre-task phase, task completion, and post task have significantly improved oral proficiency of the psychology students.

\section{V.CONCLUSION}

As the innovative ways of using CALL for the improving speaking skill purpose, the researcher has assimilated the environment of CALL with Task-Based Approach. It was structured as a series of tasks given to the students for 15 classroom sessions followed by 15 sessions of tutorial. Three types of task given: core, supporting, and synthesizing task with pre-task, during the task phase, and post-task have significantly improved the students' oral proficiency (speaking skill). The research, therefore, shows academic evidence that CALL is effective for teaching and learning speaking skill.

\section{REFERENCES}

[1] Alwasilah, A. Chaedar. 2000. Perspektif Pendidikan Bahasa Inggris di Indonesia dalam Konteks Persaingan Global

[2] Bandung: Andira.Brett, P. (1997). A comparative study of the effects of the use of multimedia on listening comprehension. System, 25(1), 39-53.

[3] Chapelle,C., and Jamieson.J.,(1986) Computer - Assisted Language Learning (CALL) as a Predictor of success in Acquiring English as Second Language. TESOL quarterly.20 (1).27- 46

[4] Coleman,Hywell.(1987).Approaches to the Management of Large Classes (Project Report No.11).
[5] Lancester-Leeds. Leeds (1997).Need analysis in Teaching English to University undergraduate in the Indonesian context: Issues \& Development. University of Leeds.Leeds

[6] Ellis,R.(2000).Task-Based research and Language Pedagogy. Language Teaching Research,4 (3).192-220.

[7] Gall, M. D., Gall. J. P., \& Borg, W. R. (2007). Educational research: An introduction (8th ed.). New York: Pearson

[8] Grace, C. A. (2000). Gender differences: Vocabulary retention and access to translations for beginning language learners in CALL. Modern Language Journal, 84(2), 214-224.

[9]Hong, W. (1997). Multimedia computer-assisted reading in business Chinese. ForeignLanguage Annals, 30(3), 335-344.

[10]Lee, L. (1997). Using Internet tools as an enhancement of C2 teaching and learning.Foreign Language Annals, 30(3), 410-427.

[11]Leppenen,S.,\& Paula.K.(1995) Experimenting with Computer Conferencing in English for Academic Purposes. ELT Journal.49 (1), 26 36

[12] Hsien.-Chin., Wang, S. H., \& Hung-Yeh, Y. (1997). Can grammatical CALL help EFLWriting instruction? CALICO Journal, 10(1), 23-43.

[13]Liu,M.\& Reed.W.M (1995). The effect of hypermedia-assistedinstruction on second language learning. Journal of Educational Computing Research, 12(2), 159-175.

[14]Long, M.H., \& Crookes, G. (1993). Three approaches to task-based syllabus design. TESOL Quarterly, 26, 27-56.

[15]McNeil,Aurelia. (2000).Computer-Assisted Instruction: Its value to second language learners. Eric Digest.No.ED 444365

[16]Mohan, B. (1992). Models of the role of the computer in second language development, In M. Pennington and V. Stevens (eds.), Computer in Applied Linguistics, Multilingual Matters, Clevedon, 110-126.

[17]Nagata, N. (1998). Input vs. output practice in educational software for second language acquisition. Language Learning and Technology, 1(2), 23-40. Retrieved February 25, 2014 from http://ltt.msu.edu/vol1 num2/article1/default.html.

[18]Nunan,D. (1989). Designing Tasks for the Communicative Classroom. Cambridge: Cambridge University Press.

$[19] \cdots \cdots \cdots \cdots \cdot .(2005)$. Aspects of Task-based Syllabus Design. Retrieved from http://www.nunan.info.

[20]Ogata, H., Feng, C., Hada, Y., \& Yano, Y. (2000). Online markup based language learning environment. Computers and Education, 34(1), 51-66.

[21]Richards. J., \& Rodgers, T. (2001). Approaches and Methods in Language Teaching. Cambridge :Cambridge University Press

[22]Skehan, P., \& Foster, P. (1997). Task type and task processing conditions as influences on foreign language performance. Language Teaching Research, 1, 185-212.

[23]Snow, M. A. (1991). Teaching language through content. In M. CelceMurcia (Ed.), Teaching English as a second or foreign language (pp. 315328). Boston: Heinle and Heinle.

[24]Sullivan, N., \& Pratt, E. (1996). A comparative study of two ESL writing environment: a computer-assisted classroom and a traditional oral classroom. System, 24(4), 491-501.

[25]Thorson, H. (2000). Using the computer to compare foreign and native language writing processes: A statistical and case study approach. Modern Language Journal, 84(2), 155-170.

[26]Ur,P.(1999). A Course in Language Teaching:Practice and Theory.Cambridge:Cambridge University Press.

[27]Warschauer, M (1996). Computer-Assisted Language Learning: An introduction. In S. Fotos (Ed.), Multimedia Language Teaching (pp.3-20). Tokyo: Logos Int.

[28]Zhengdong,Gan (2012). Understanding L2 Speaking Problems: Implications for ESL Curriculum Development in a Teacher Training Institution in Hong Kong. Australian Journal of Teacher Education, 37(1). 